UDC 621.391

\title{
INCREASING THE ACCURACY OF DETERMINING THE COORDINATES OF ELEMENTS OF WIRELESS SENSOR NETWORKS
}

\author{
Leonid O. Uryvsky, Evgeniy A. Yakornov, Oleg F. Tsukanov \\ "Igor Sikorsky Kyiv Polytechnic Institute", Kyiv, Ukraine
}

Background. Modern methods for determining the coordinates of elements of wireless sensor networks allow solving problems with a single determination and errors in determining the mutual distances between elements of a wireless network. In the case of increasing requirements for the accuracy of determining the coordinates of network elements, existing methods do not allow solving the problem.

Objective. Improving the accuracy of estimating the coordinates of elements of wireless sensor networks based on multiple measurements of distances between network elements.

Methods. The determination of the coordinates of the elements of wireless sensor networks is implemented in two stages. At the first, by repeatedly measuring the mutual distances between the elements, an estimate of the coordinates and a correlation matrix of errors in estimating the coordinates of the elements of the wireless s ensor network are determined. In the second, in order to improve the accuracy and ensure the stability of the estimation process, an adaptively regularized Kalman filtering algorithm is proposed to refine the coordinate estimates and the correlation matrix of errors

Results. The proposed method, based on the adaptive-regularized estimation algorithm, according to the results of simulation, allows increasing the accuracy of estimating the location parameters of wireless sensor networks by an average of $12-16 \%$ and at the same time provides stability and convergence of the estimation process.

Conclusions. The considered method for determining the coordinates of elements of wireless sensor networks can be implemented in modern terrestrial sensor networks for various purposes.

Keywords: wireless sensor network; coordinate elements of wireless sensor networks; adaptive-regularization filtering algorithm.

\section{Introduction}

The wireless sensor network (WSN) is a complex technical system: self-organizing, distributed, fail-safe operation of individual sensors (elements) of ultrasmall stand-alone technical devices. All or some elements provide the transfer of information reception among themselves on a large plane. Modern sensory systems use network management and monitoring facilities, the quality of the WSN operation is determined by the modern technologies in which they are applied. WSN can be used in airborne detection systems [1], navigation systems for high-precision determination of their coordinates and control of unmanned aerial vehicles [2]. For operation, such systems require the determination of the coordinates of the elements and their errors with high accuracy.

The purpose of developing a new method is to improve the accuracy and stability of the estimation of the coordinates of individual sensors (elements) in wireless sensor networks with multiple measurements of distances between elements. The accuracy of the estimation of the coordinates of the elements significantly affects the characteristics of the WSN, for example, when using the WSN elements as pseudosatellites (translators) to ensure the landing of aircraft at airports.

Currently, the basic exchange protocol for WSM is IEEE 802.15.4 (ZigBee), which provides the ability to measure the distance between network elements by the power level of the received signal [3]. The accuracy of estimating the coordinates of the elements depends on many factors, the main of which are determined by the propagation conditions and the power level of the received radio signals, that is, depends on errors in measuring the distances between the elements. Existing methods for estimating the coordinates of elements do not allow obtaining the required accuracy and stability of estimates, for example, for navigation systems.

The aim of the work is to describe a new method for increasing the accuracy of estimating the coordinates of the WSN elements by repeatedly measuring distances between network elements.

\section{Formulation of the problem}

The mathematical statement of the problem of estimating the coordinates of the WSM elements looks as follows. In the space region, random elements of the WSN are distributed uniformly. Each $i$-th WSM element $(i=\overline{1, M})$ is connected with neighboring elements and can determine distances $d_{i j}$ up to them. Errors in measuring the distance $\rho_{i j}$ are also known.

On the basis of these data, it is necessary to determine the estimates of the coordinates $\mathrm{X}_{\mathrm{n}}$ and the correlation error matrix for estimating the coordinates of the elements $K_{n}$ and further refine their value after the next stage of measuring the distances between 
neighboring elements. The need for constant refinement of the coordinates of the WSN is conditioned by the requirements for obtaining highly accurate estimates of the coordinates of the elements (in modern navigation systems up to several centimeters). Errors in measuring the distances between elements are determined by many factors and depend on the seasonal, temporal instability of the Earth's gravitational field, on the propagation conditions of radio waves. And taking into account the limited computing resources of the WSN elements, the small capacity of the autonomous power supplies of the elements, the coordinate estimates should be determined using a recurrent, stable estimation algorithm, which is proposed as a regularized adaptive Kalman filter.

\section{Determining the coordinates of the WSN elements}

Consider an WSN consisting of $\mathrm{M}$ elements and deployed on a flat surface of the Earth. The local rectangular coordinate system is arranged as follows (Fig. 1): the first element is located at the origin of the coordinate system, the second is on the $\mathrm{X}$ axis, the $\mathrm{Y}$ axis lies on the Earth's surface, the $Z$ axis complements the system to the right triple of coordinates. Since the $z_{i}$ coordinates do not vary much, so we restrict ourselves to the two-dimensional case in which the coordinates of each WSN element $\quad \mathrm{X}_{i}{ }^{T}=$ $\left(x_{i}, y_{i},\right)$, based on the distance $\mathrm{d}_{\mathrm{ij}}$ between neighboring elements $i, j$. by analyzing the received signal strength from neighboring WSN elements by the RSSI (Received-Signal-Strength-Indicator) method.

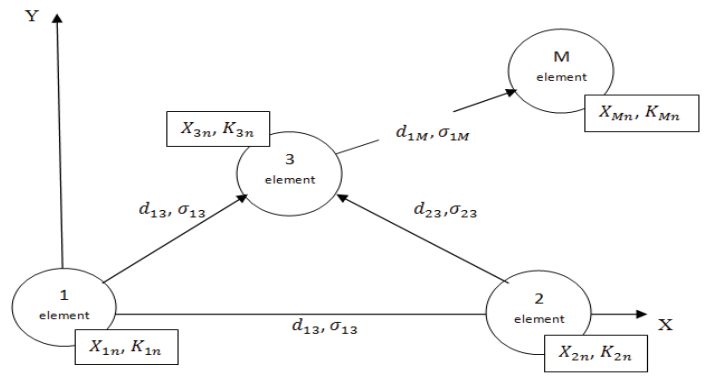

Fig.1. M - elemental WSN.

A hypothesis is accepted about the normal error distribution law for measuring distances between network elements $\mathrm{N}\left(0, \rho_{i j}\right)$, with zero mathematical expectation and variance $\rho_{\mathrm{ij}}$. The dispersion of errors in measuring distances between elements is determined by the distance measurement method (differenceranging, difference-hyperbolic method).

Based on the known methods of measuring distances $[3,4]$, an estimation method is proposed that makes it possible to carry out the following transformations:

$$
\left\{d_{i j} \rightarrow X_{i n}\right\},\left\{\rho_{i j} \rightarrow \mathrm{K}_{i n}\right\}, \quad i, j \in \overline{1, \mathrm{M}} .
$$

Thus, the cumulative estimate of the coordinates of the elements consists of the following information: - state vector $X_{i n}{ }^{T}=\left(x_{i}, y_{i}\right)$;
- the correlation matrix of errors in the estimation of coordinates $K_{\text {in }}=\operatorname{cov}\left(\mathrm{X}_{i}{ }^{T}, \mathrm{X}_{i}\right)$, which characterizes the accuracy of the estimation of the state vector $\mathrm{X}_{\text {in }}$.

Based on the rangefinder method, the coordinates of the element $\left(x_{3}, y_{3}\right)$ based on the measured distances $d_{13}, d_{23}$ and the known coordinates of the elements $\left(x_{1}, y_{1}\right)$ and $\left(x_{2}, y_{2}\right)$ are determined:

$$
\begin{aligned}
& d_{13}=\sqrt{\left(x_{1}-x_{3}\right)^{2}+\left(y_{1}-y_{3}\right)^{2}}, \\
& d_{23}=\sqrt{\left(x_{2}-x_{3}\right)^{2}+\left(y_{2}-y_{3}\right)^{2}},
\end{aligned}
$$

and the coordinate estimates $\left(x_{3}, y_{3}\right)$ are determined using a nonlinear method least squares (MLS),

$$
\begin{aligned}
& \mathrm{X}_{\kappa}=\mathrm{X}_{\kappa-1}+\left(\mathrm{A}\left(\mathrm{X}_{\kappa-1}\right)^{T} \mathrm{~A}\left(\mathrm{X}_{\kappa-1}\right)\right)^{-1} \times \\
& \mathrm{A}\left(\mathrm{X}_{\kappa-1}\right)^{T}\left(\mathrm{D}-\varphi\left(\mathrm{X}_{\kappa-1}\right)\right),
\end{aligned}
$$

where $\kappa$ - step iteration,

$$
\begin{gathered}
\varphi\left(\mathrm{X}_{\kappa-1}\right)=\mathrm{D}=\left|d_{13}, d_{23}\right|^{T}, \quad \mathrm{X}_{\kappa}=\left|x_{3}, y_{3}\right|^{T}, \\
\left|\sqrt{\left(x_{1}-x_{3}\right)^{2}+\left(y_{1}-y_{3}\right)^{2}}, \sqrt{\left(x_{2}-x_{3}\right)^{2}+\left(y_{2}-y_{3}\right)^{2}}\right|^{T}, \\
\mathrm{~A}(\mathrm{X})=\left(\begin{array}{ll}
\frac{\partial d_{13}}{\partial x_{3}} & \frac{\partial d_{13}}{\partial y_{3}} \\
\frac{\partial d_{23}}{\partial x_{3}} & \frac{\partial d_{13}}{\partial y_{3}}
\end{array}\right),
\end{gathered}
$$

calculations ends when:

of calculations.

$$
\left\|\mathrm{X}_{\kappa}-\mathrm{X}_{\kappa-1}\right\| \leq \varepsilon, \quad \varepsilon-\text { required error }
$$

Correlation matrix of errors in estimating the coordinates of the WSN elements $K_{i n}$ is determined by the variances of the measurement of distances $\rho_{i j}$ between neighboring elements

$$
\widetilde{K_{\kappa}}=\left(\mathrm{A}\left(\mathrm{X}_{\kappa-1}\right)^{T} \mathrm{~A}\left(\mathrm{X}_{\kappa-1}\right)\right)^{-1} \sigma_{d}
$$

the matrix $\sigma_{d}$ has the form:

$$
\sigma_{d}=\left|\begin{array}{cc}
\rho_{13} & 0 \\
0 & \rho_{23}
\end{array}\right|
$$

The disadvantage of the algorithm under consideration is the necessity of iterations. The coordinates of the element located at the beginning of the local coordinate system must be determined with high accuracy, for example, using the GPS system. If practical implementation of such measurements is possible, then the algorithm considered allows one to obtain the most accurate estimation accuracy. The initial coordinates of the elements determined by GPS are considered reference, so they can be used to calibrate the determination of the distance between the elements of the WSN.

\section{Description of the regularized-adaptive filering algorithm}

For equal distances between adjacent elements of the WSN, the MLS can be used to refine the estimate of the coordinates of each element, and in the case of unequal distances, a recurrent algorithm of dynamic estimation (dynamic filtering based on the Kalman filter [5]) should be applied, to the advantages of which is a relatively small amount of computing resources. 
The initial conditions of the dynamic filtering algorithm are the vector of the values of the coordinates $X_{n-1}$ and the correlation error matrix $K_{n-1}$ after the n-1 measurement step.

As a measurement vector, the value of the coordinate vector $\mathrm{X}_{i n}$ and its correlation error matrix $\mathrm{Q}_{\text {in }}$ are taken at the nth step of the measurements.

In this case, the extrapolated values of the coordinate vector and the correlation matrix take the form

$\mathrm{X}_{\mathrm{in}}^{\mathrm{e}}=\mathrm{X}_{\mathrm{in}-1}$,

$\mathrm{K}_{\mathrm{in}}^{\mathrm{e}}=\mathrm{K}_{\mathrm{in}-1}$

and the matrix gain

$$
H_{\text {in }}=K_{i n}^{e}\left(K_{i n}^{e}+\mathrm{Q}_{i n}\right)^{-1}
$$

Then the estimates $\widehat{X_{l n}}, \widehat{K_{l n}}$ are represented by the relations

$$
\begin{aligned}
& \widehat{X_{i n}}=X_{i n}+H_{i n}\left(\mathrm{X}_{i n}-X_{i n}^{e}\right), \\
& \widehat{K_{\text {in }}}=K_{i n}^{e}-K_{i n}^{e} H_{i n},
\end{aligned}
$$

where $H_{\text {in }}$ is the matrix gain of the dynamic filter.

$\widehat{X_{l n}}=\left(\widehat{x}_{l}, \widehat{y}_{\imath}\right)^{T}$, evaluation of the state vector,

$\widehat{K_{\iota n}}=\left(\begin{array}{cc}\sigma x^{2} & s_{x y} \\ s_{x y} & \sigma y^{2}\end{array}\right)$, the correlation matrix of errors $\sigma x^{2}, \sigma y^{2}-$ variance of the estimate, $s_{x y^{-}}$mutual correlation moment with respect to the coordinates $x, y$.

Using the Kalman filter, the estimation vector $\widehat{X_{l n}}$ and the correlation matrix of the estimation error $\widehat{K_{\iota n}}$ of the coordinates for each element are refined. Each time the WSN elements measure distances and the error in determining the distance to neighboring elements, their coordinates and correlation error matrix are refined.

It is known [6] that Kalman's dynamic filtering algorithm provides: firstly, knowledge of the dynamic model of the system, and secondly, it is necessary to fulfill the condition of "normality" of the law of distribution of measurement errors with zero mathematical expectation and a known correlation matrix. In practice, such conditions are difficult to implement, and in most cases impossible. Therefore, to ensure stability and improve the accuracy of the estimation, the dynamic filtering algorithm should be modified.

Note that the matrix gain $H_{\text {in }}$ is calculated without taking into account the values of the measurement vector $\mathrm{X}_{\text {in }}$ using the correlation matrices of estimation errors $\overline{K_{l-1 n}}$ and measurement errors $Q_{i n}$.

The following variants are possible with an increase in the number of steps $n$ :

1) as $\mathrm{n}$ increases, the elements of the matrix gain $H_{\text {in }}$ tend to zero:

$$
\begin{aligned}
& \lim _{n \rightarrow \infty} H_{i n}= \\
& \lim _{n \rightarrow \infty} \widetilde{K_{l-1 n}}\left(\widetilde{K_{l-1 n}}+\mathrm{Q}_{i n}\right)^{-1}=0,
\end{aligned}
$$

$H_{\text {in }} \rightarrow 0$, и $H_{\text {in }}\left(\mathrm{X}_{\text {in }}-X_{i n}^{e}\right) \rightarrow 0$, then $\widehat{X_{\text {in }}}=X_{i n-1}, \widehat{K_{\text {in }}}$ $=K_{i n-1}$, and there is no filtration;

2) because some elements of the matrix

$\left(\widetilde{K_{l-1 n}}+\mathrm{Q}_{i n}\right)^{-1} \rightarrow 0$, as $\mathrm{n} \rightarrow \infty$, both the elements of the matrix $\overline{K_{l n-1}}$ and the matrix $\mathrm{Q}_{i n-1}$.
And this means that when the traffic flow increases between the elements of the WSN, the accuracy of estimating the coordinates of the network elements increases, on the one hand, and, on the other hand, this process simultaneously leads to a violation of the stability of the algorithm.

Therefore, the task of ensuring the stability of the dynamic filter should be solved by simultaneously limiting the bottom and top values of the elements of the matrix gain $\overline{K_{l-1 n}}$. Elements of the matrix $\mathrm{Q}_{\text {in-1 }}$ are determined by the distance measurement method. If the matrix $\mathrm{Q}_{i n-1}$ tends to zero with increasing $\mathrm{n}$, then it is necessary to artificially restrict the values of the elements $\overline{K_{l-1 n}}$ from below.

The paper proposes to combine the regular and adaptive Kalman filtering algorithms. Regularized filtering algorithms are used in the case of divergence of the estimation process, which arises in connection with the lack or insufficient volume of a priori information about the measurement vector. A consequence of this can be the general absence of the possibility of calculating the gain $H_{\text {in }}$ due to the fact that $\left(\widetilde{K_{l-1 n}}+\mathrm{Q}_{i n-1}\right)^{-1}$ does not have an inverse matrix. Also, the regularized filtering algorithm allows for a steady increase in $Q_{i n-1}$ ) - measurement noise to ensure stable operation [7]. Under such conditions, the matrix gain can be calculated as

$$
H_{\text {in }}=\widetilde{K_{\text {ln-1 }}}\left(\widetilde{K_{\text {ln-1 }}}+\alpha \mathrm{Q}_{\text {in }-1}\right)^{-1} \text {, }
$$

here $\alpha \in[0,1]$ - the regularization parameter is defined

$$
\left\|\mathrm{X}_{\text {in }}-X_{\text {in }}^{e}\right\| \leq p \text {. }
$$

It should be noted that the regularization parameter $\alpha$ can be determined for any topological space, starting from the law of distribution of measurement errors. For example, for a space with a quadratic norm, the gain $H_{\text {in }}$ can be determined under the condition:

$$
\sum\left(\mathrm{X}_{\text {in }}-X_{\text {in }}^{e}\right)^{2} \leq p,
$$

where $\Sigma$ - operation of elementwise addition.

The method of limiting the gain $H_{\text {in }}$ can also be referred to the regularization methods. Limitations of $H_{\text {in }}$ are practically possible with the dimension of the matrix $2 \times 2,3 \times 3$, otherwise the method is inappropriate.

Estimates of the parameters in the case of the regularization application will be stable provided that the error in the results of the processing is consistent with the measurement error.

This is eliminated in the adaptive filtering algorithm, the gain $H_{i n}$ in which is determined taking into account the discrepancy $X_{i n}-X_{i n}^{e}$, and therefore a priori information on the statistical characteristics of measurement errors is not required.

Then the adaptive algorithm for determining the matrix gain has the form

$$
\begin{aligned}
& H_{i n}=\widetilde{K_{l-1 n}}\left(\mathrm{I}\left(\mathrm{X}_{i n}-X_{i n}^{e}\right)^{2}\right)^{-1}, \\
\text { if } \Lambda> & \Delta, \\
& H_{i n}=\widetilde{K_{l-1 n}}\left(\widetilde{K_{l-1 n}}+\mathrm{Q}_{i n}\right)^{-1}, \\
\text { else } \Lambda \leq & \Delta . \\
& \mathrm{I}\left(\mathrm{X}_{i n}-X_{i n}^{e}\right)^{2}=\Lambda, \\
& \overline{K_{l-1 n}}+\mathrm{Q}_{i n}=\mathrm{V} \Delta \mathrm{V}^{\mathrm{T}},
\end{aligned}
$$


where $\Lambda, \Delta$ - diagonal matrices of eigenvalues of size $m \times m$, and the matrices $V, V^{T}$ in the general case are two unitary matrices consisting of right and left singular vectors, respectively, with $V V^{T}=\mathrm{I}$.

In the adaptive filter, the upper value of $H_{\text {in }}$ is limited to the square of the residual, and the lower value in (13) tends to $0\left(H_{\text {in }} \rightarrow 0\right)$, as $\mathrm{n}$ increases, which leads to instability of the filtration process. To ensure stability at $\Lambda \leq \Delta, \quad H_{\text {in }}$ is determined using a regularized filtering algorithm (9).

Note that (12) and (14), taking into account (9), are expressions for calculating the gain of the regularized-adaptive Kalman filter [5].

For comparison of the considered filtering algorithms, the results of the simulation (Fig. 2) simulation of the dependence of the position of the $\mathrm{i}$-th element on the coordinate $x$ (in meters) on the number of measurements $n$ are presented. The input data for the simulation model are the number of WSN elements M and the distances between them $d_{i j}{ }^{i n}$. Next, an imitation of the "noise" of these quantities by a random process with a normal distribution law $\mathrm{N}\left(0, \rho_{i j}{ }^{i n}\right)$ is performed with zero mathematical expectation and a given variance $\rho_{i j}{ }^{i n}$. Estimations of the coordinates $\mathrm{X}_{\text {in-1 }}$ and $\mathrm{K}_{\mathrm{in}-1}$ of the correlation matrix of estimation errors are determined by the ranging method (2), (3).

These data are the initial conditions for filtering algorithms. Further in the WSN, after the next measurement of the distance between adjacent elements, the estimations of the coordinates $\mathrm{X}_{\text {in }}$ and the correlation error matrix $\mathrm{Q}_{\text {in }}$ are determined. These values are simultaneously a measurement vector and a measurement error matrix for regularized, adaptive, and regularized-adaptive filtering algorithms.

The results of the simulation allow us to state that the proposed regularized adaptive Kalman filter with multiple measurements of the distances between elements of the WSN allows obtaining stable estimates which, in addition, improve the accuracy of determining the coordinates of the WSN elements, including in the absence of reliable a priori information on errors in measuring distances.

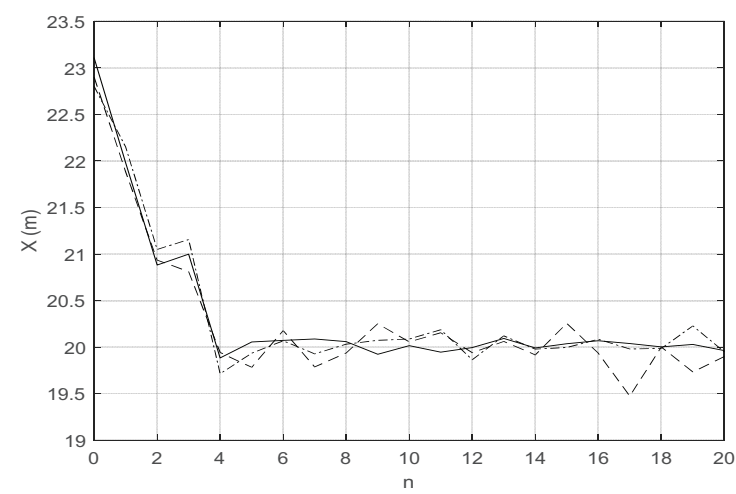

Fig. 2. Regularization of the filter - dashed line, adaptive filter - a dot-and-dash line,

regular-adaptive-filter - solid line.

\section{Conclusion}

Thus, the problem of estimation and errors in determining the coordinates of the WSN elements with multiple measurement of the distances between network elements can be reduced to two stages:

1) on the basis of the information on the measurement of distances and the error in their determination between neighboring elements in the local coordinate system by the distance-measuring method, the coordinates and errors in determining the coordinates of the WSN elements are determined;

2) to ensure stability and improve the accuracy of the assessment, the coordinates of the elements are refined for multiple measurements of the distances between neighboring network elements by applying a regularadaptive filtering algorithm.

Mathematical modeling confirms the stability and convergence of the filtration process, while the accuracy of estimating the coordinates of the WSN network elements after four measurement cycles increases by an average of $12-16 \%$ compared to known estimation methods.

\section{References}

[1] Lysenko O., Uryadnikova I., Valuiskyi S., Nechyporenko I. A method of controlling the topology of aerial repeaters network to improve structural information connectivity of wireless ad hoc networks Liptovsky Mikulas, Slovak Republic: Armed Forces Academy. Science\&Military, №1, Volume 7, 2012, p. 62-71. ISSN 1336-8885.

[2] Kashuba S., Novikov V., Alekseeva I., Lysenko O. Optimization of Unmanned Aerial Vehicle Path for Wireless Sensor Network Data Gathering. 3rd International Conference: Actual problems of unmanned aerial vehicles developments (APUAVD2015) October 13-15, 2015 Organized by IEEE Ukraine Section Joint SP/AES Chapter and the National Aviation University (Kyiv), p.280-283.

[3] Langdon M. "ZigBee goes underground", E\&T Magazine, 2009, Aug.

[4] Voroshilin E.P. Determination of the coordinates of radio emission sources, // M.V. Mironov, V.A. Gromov. TUSUR reports, No. 1 (21), part 2, 2010

[5] Grewal M.S., Andrews A.P., "Kalman Filtering Theory and Practice Using MATLAB", Wiley, 2001.

[6] Batishchev V. I, "Principles for the construction of stable regularized Kalman filters"// Samara State Technical University, Samara, 2000, 151-156.

[7] Ali Hussein Hasan, Aleksandr N. Grachev Adaptive $\beta-\alpha$ - filter for Target Tracking Using Real Time Genetic Algorithm // Journal of Electrical and Control Engineering. 2013. Vol. 3, No. 4. P. 32-38. 
Уривський Л.О., Якорнов С.А., Цуканов О.Ф.

Підвищення точності визначення координат елементів бездротових сенсорних мереж

Проблематика. Сучасні методи визначення координат елементів бездротових сенсорних мереж дозволяють вирішувати завдання при одноразовому визначенні і помилок визначення взаємних відстаней між елементами бездротової мережі. У разі підвищення вимог до точності визначення координат елементів мережі, існуючі методи не дозволяють вирішити поставлену задачу.

Мета дослідження. Підвищення точності оцінювання координат елементів бездротових сенсорних мереж на основі багаторазового вимірювання відстаней між елементами мережі.

Методика реалізації. Визначення координат елементів бездротових сенсорних мереж реалізується в два етапи.

На першому, шляхом багаторазових вимірювань взаємних відстаней між елементами визначається оцінка координат і кореляційна матриця помилок оцінювання елементів бездротової сенсорної мережі.

На другому, з метою підвищення точності і забезпечення стійкості процесу оцінювання, пропонується адаптивно-регулярізований алгоритм калмановської фільтрації для уточнення оцінок координат і кореляційної матриці помилок.

Результати дослідження. Запропонований метод на основі алгоритму адаптивно-регуляризованого алгоритму оцінювання, за результатами імітаційного моделювання, дозволяє підвищити точність оцінювання параметрів розташування елементів бездротових сенсорних мереж в середньому на $12-16 \%$ і при цьому забезпечується стійкість і збіжність процесу оцінювання.

Висновки. Розглянутий метод визначення координат елементів бездротових сенсорних мереж може бути реалізований в сучасних наземних сенсорних мережах різноманітного призначення.

Ключові слова: бездротова сенсорна мережа, координат елементів бездротових сенсорних мереж, адаптивно-регулярізованій алгоритм фільтрації.

Урывский Л.А., Якорнов Е.А., Цуканов О.Ф.

Повышение точности определения координат элементов беспроводных сенсорных сетей

Проблематика. Современные методы определения координат элементов беспроводных сенсорных сетей позволяют решать задачи при однократном определении и ошибок определения взаимных расстояний между элементами беспроводной сети. В случае повышения требований к точности определения координат элементов сети, существующие методы не позволяют решить поставленную задачу.

Цель исследования. Повышение точности оценивания координат элементов беспроводных сенсорных сетей на основе многократного измерения расстояний между элементами сети.

Методика реализации. Определение координат элементов беспроводных сенсорных сетей реализуется в два этапа.

На первом, путем многократных измерений взаимных расстояний между элементами определяется оценка координат и корреляционная матрица ошибок оценивания координат элементов беспроводной сенсорной сети.

На втором, с целью повышения точности и обеспечения устойчивости процесса оценивания, предлагается адаптивно-регуляризованый алгоритм калмановской фильтрации для уточнения оценок координат и корреляционной матрицы ошибок.

Результаты исследования. Предложенный метод на основе алгоритма адаптивно-регуляризованного алгоритма оценивания, по результатам имитационного моделирования, позволяет повысить точность оценивания параметров местоположения элементов беспроводных сенсорных сетей в среднем на $12-16 \%$ и при этом обеспечивается устойчивость и сходимость процесса оценивания.

Выводы. Рассмотренный метод определения координат элементов беспроводных сенсорных сетей может быть реализован в современных наземных сенсорных сетях различного назначения.

Ключевые слова: беспроводная сенсорная сеть, координат элементов беспроводных сенсорных сетей, адаптивно-регуляризований алгоритм фильтрации. 